\title{
Beyond Translated vs. Indigenous: Turkish Protestant Christian Hymnody as Global and Local Identity
}

\author{
Jeremy Perigo
}

Citation: Perigo, Jeremy. 2021. Beyond Translated vs. Indigenous: Turkish Protestant Christian Hymnody as Global and Local Identity. Religions 12: 905. https:// doi.org/10.3390/rel12110905

Academic Editor: Edward Foley

Received: 16 August 2021

Accepted: 15 October 2021

Published: 20 October 2021

Publisher's Note: MDPI stays neutral with regard to jurisdictional claims in published maps and institutional affiliations.

Copyright: (C) 2021 by the author. Licensee MDPI, Basel, Switzerland. This article is an open access article distributed under the terms and conditions of the Creative Commons Attribution (CC BY) license (https:// creativecommons.org/licenses/by/ $4.0 /)$.
Worship Arts Department, Dordt University, Sioux Center, IA 51250, USA; jeremy.perigo@dordt.edu

\begin{abstract}
At Turkey's first national worship conferences in 2011, a passionate debate arose on whether Western music or indigenous Turkish music was most appropriate for worship. Some Turks felt that the Western missionaries were imposing indigenous musics on Turks as a type of "reverse colonization". They felt that the current Western musical styles were best for worship. One Turk stated, "the saz is being forced down our throats". Other Turks felt liberated to sing and play songs in traditional Turkish musical styles. The debate at the conference highlights the desire of missionaries and Turks to see renewal in congregational hymnody. Nevertheless, the Western vs. indigenous Turkish music debate reduces complex historical, musical, and liturgical issues into a divisive binarism. Using hymns sung in corporate worship in Turkey as a source, I will analyze here the quantity of musical localization in Turkish Protestant worship seeking to present musical localization as a lens to examine Turkish Christian liturgical identity.
\end{abstract}

Keywords: Turkish Christianity; musical translation; contemporary Christian worship music; hymnody; missiology; liturgical identity

In late 2011, a passionate discussion arose at one of the first national worship conferences in Turkey. The debate considered musical styles and genres appropriate for Turkish worship. A breakout seminar entitled "Expressing Our Heart to God, Using Turkish Instruments and Music Styles" was held. During the discussion, a tense debate arose on whether Western music or indigenous Turkish music was most appropriate for worship. ${ }^{1}$ Some Turks felt that the Western missionaries were imposing indigenous and traditional music on Turks as a type of reverse colonization. They felt that the current Western musical styles were best for worship. One Turk stated, "The saz is being forced down our throats". ${ }^{2}$ Other Turks felt liberated to sing and play songs in traditional Turkish musical styles "for the first time in their life". ${ }^{3}$ The debate at the conference highlights the desire of missionaries and Turks to see renewal in congregational hymnody. Nevertheless, the debate of Western translations vs. indigenous Turkish music lacks historical analysis critical for understanding Turkish liturgical identity. ${ }^{4}$

\section{Localization, Identity, and Contemporary Christian Worship}

Though some recent scholarship has focused on localization of Contemporary Christian Worship in local Christian communities, limited studies on Christian worship music and identity in the Turkish Protestant context exist (Whittaker 2019; Clark 2012). The interplay of Western hymnody and indigenous worship identity featured in this volume, "Language Translation in Localizing Religious Musical Practice", is gaining interest from ethnographers, ethnomusicologists, and theologians. Broadly, Ingalls, Landau, and Wagner highlight that " $(\mathrm{m})$ usic often serves a central role in processes of identification within religious communities because collective music-making allows for the negotiation of religious identities in dialogue with those of race/ethnicity, national and religious affiliations, generational difference and denominational or parachurch affiliations" ${ }^{5}$ In his research on formation and congregational song in China, Swee Hong Lim observes an "interdependent relationship" between musicking and community. He states, "In this relationship, the 
community relies on musicking for its construction, while the relevance of musicking is authenticated by the community's continued use" (Lim 2017). A local community's expression of belief and identity through the singing of songs from outside their context may not fit into tidy geopolitical or regional identifiers, such as Western vs. indigenous; instead, the localization of congregational song reflects what Marcell Steuernagel calls "messiness" (Steuernagel 2021, p. 155). In viewing congregational song as a performance ritual within cultural contexts, Steuernagel uses "messiness" to "recognize the fluidity of the cultural flows that result from play in the context of church music" (Steuernagel 2021, p. 155). Ingalls, Reigersberg, and Sherinian propose "musical localization" as a category to view the diverse "process Christian communities worldwide adapt, adopt, create, perform, and share congregational music" (Ingalls et al. 2018, p. 13). They define musical localization as "the process whereby Christian communities take a variety of musical practices-some considered "indigenous", some "foreign", some shared across spatial and cultural divides; some linked to past practice, some innovative - and make them locally meaningful and useful in the construction of Christian beliefs, theology, practice, and identity" (Ingalls et al. 2018, p. 13). Taxonomies such as Western or indigenous or even hybridity are inadequate in characterizing the relationship between the origins of songs sung and the worship identities within a local congregation.

Resonating with this research, Fiona Magowan's study of Yolngu in the northeast Arnhem Land of Australia reveals that though the Yolngu's musical worship emerged from the hymnody and liturgy of Methodist missions, a charismatic revival in 1979 on Galiwin'ku significantly altered the style of worship and hymnody of this indigenous people (Magowan 2007). Influenced by these circumstances, the songs presented by Yolngu at worship rallies embody both local and global identities. Magowan points out:

On the one hand, many of the songs performed come from a non-Indigenous charismatic tradition and present universal and generic ideas of Christian love, belonging to community, and care for one another. These songs are positioned beside a translocal tradition of Indigenous Christian composition that is shared across communities of the Arnhem Land region. (Magowan 2007, p. 471)

A dichotomy of Western vs. indigenous hymnody seems to be minimized in the postrevival Yolgnu context, where Yolngu find identity and meaning through local worship music and music from outside their community. Magowan writes, "The absorption of a universalist body of contemporary Christian music by Indigenous Christians means that they can participate in a worldwide arena that offers the potential for reconciliation between Indigenous and non-Indigenous groups and that speaks to their own experience of charismatic song" (Magowan 2007, p. 478). Yolgnu participate in the songs and sentiments of a global Christian worship movement, yet simultaneously, they find local expressions of worship identity through localized hymnody.

Studies of Turkish Protestant hymnody and identity are scant; therefore, this article is an initial inquiry into the negotiation of worship identities within Turkish Protestant churches investigating the origins of congregational song in local churches. In recent scholarship, liturgical scholars and historians examined popular worship songs to elucidate theological beliefs and liturgical theologies through UK and USA CCLI lists.(Wood and Walrath 2007; Thornton 2021) Within the Turkish context, no such copyright administrator or relevant data exists. Instead, data from a 2011 survey of eighteen churches' songs sung in corporate worship along with data from Worship Leader (Turkish) electronic hymnal, served as sources to analyze musical localization. This paper serves as an extension of the study of contemporary praise and worship music and identity to aid in locating the cultural flows related to congregation song within Turkish Protestant Christianity.

Using hymns sung corporate worship in Turkey as a source, I will analyze here the quantity of localized songs in Turkish Protestant worship in eighteen churches in 2011. Interviews with Turkish worship leaders and foreign ministers serving in Turkey will illustrate and refine the character of localization in this song analysis. Through a historical review of the multi-faceted tensions in musical style and identity during the musical 
"reforms" at the founding of the Turkish Republic, along with discussion on the cultural and musical environment of Turkish Protestant worship, I will establish "localization" as a viable lens for viewing Turkish hymnody.

\section{Identity Reform or Repression? Musical Tensions at the Birth of the Turkish Republic}

Western music has influenced traditional Turkish music for the past two centuries as Western performers were invited to play for the Sultans. Sufi Dervishes experimented with the piano in the Sema, and Turks quickly adapted operetta, tango, and jazz during the late Ottoman period (Stokes 2011, pp. 18-19; Öncel n.d., pp. 25, 30 and 82). However, the most striking reforms in traditional Turkish music occurred in the 1920s and 1930s as part of the cultural reforms during the birth of the modern Turkish Republic. As the new Turkish Republic was being formed, radical reforms in Turkish culture were instituted to modernize what was left of the Ottoman Empire. Under Mustafa Kemal Ataturk, the founder and first president of Turkey, political, cultural, religious, and economic reforms were quickly instituted to create a secular, modern nation. Modern Sufi musician, Kudsi Erguner, writes, "This very new Republic was trying to involve itself in new cultural forms, and to take European culture as a model" (Erguner 2005, pp. 38-39). The attempts to Westernize and Europeanize Turkey were swift. Erguner continues, "We Turks did not have the time to go through all these stages of evolution (at least this is what was commonly claimed by the elite). We had to catch up and assimilate at once to obtain the beneficial effects of progress" (Erguner 2005, p. 39). Ataturk's reforms were extended to Turkish music, as he and Ziya Gökalp attempted to define and create a new national music (Bates 2011, p. 75).

As part of the musical reforms, by 1925, Ottoman art music and the Islamic Sufi music of the Dervish lodges were officially banned (Bates 2011, p. 34). The reformers desired to adapt Ottoman classical music to resemble Western music. In a 1934 address to Parliament, Ataturk stated:

A measure of the change undergone by a nation is its capacity to absorb and grasp a change in music. The music that they are trying to get people to listen to today is not our music, so it can hardly fill the bill. We must not lose sight of this fact. What is required is the collection of national expression that conveys fine thoughts and feelings, and without delay, putting it to music, along the lines of the most modern of rules. Only in this way can Turkish music rise to take its place among the music of the world. ${ }^{6}$

The reforms aimed to create a Turkish national musical expression that would be respected by the world. Gökalp stated, "If only our national culture welds with our new civilization (the West) can one speak of a national music". ${ }^{7}$ This desire led to a twentymonth radio ban of Turkish music from 1934-1935, where only Westernized Turkish music could be played. ${ }^{8}$ Of the new music, Bates writes, "In contrast to the music's traditional small-ensemble aesthetic, new government-sponsored performances and radio broadcast involved large, heterogeneous ensembles of Turkish and Western art-music instruments" (Bates 2011, p. 34). In addition to the changes of art music and the banning of the Dervish lodge, Turkish folk tunes were collected, reharmonized, and notated according to Western musical conventions. Erguner criticizes the reforms stating that "this solution meant denying the whole of our true cultural, literary and musical heritage" (Erguner 2005, pp. 38-39). While some Turks resonated with Ataturk's reforms identifying Turkishness with these Westernized forms, many did not embrace the musical reforms and continued to listen to and perform traditional Turkish music while others began listening to Arabic music. $^{9}$

A 2008 Turkish satirical short film directed by Sinan Çetin entitled Mutlu Ol! Bu Bir Emirdir $!^{10}$ highlights this deep-rooted musical tension within Turkish culture as Turkish soldiers break into a traditional home where musicians are performing traditional music. At gunpoint, they force the musicians to stop playing halk türküsü, a style of Turkish music. The Turkish soldiers then proceed to demand that the musicians can only play compositions by 
Western composers. The soldiers humorously mispronounce the names of the composers Chopin, Verdi, Wagner, and others as they read a list of government-approved music. The saz player proceeds to play Beethoven's Ode to Joy as a halk türküsü. The singers join in, and the soldiers begin dancing and singing in traditional forms. The film ends by stating, "The political authorities that forbid people's music, culture and lifestyles have always fallen into an awkward position against life itself". ${ }^{11}$ The film highlights the tension in Turkish culture. Many perceived these actions as important reforms in Turkish music and cultural identity, while others felt the actions were a repression of genuine Turkishness. Nonetheless, from within this tension of Western vs. indigenous, new musical forms have emerged that, for many Turks, are deeply embedded into their Turkish identity.

\section{Turkish Musical Fusion, Localization, and Cultural Identity}

Although not fully embraced, the musical reforms of Ataturk and Gökalp have had a strong impact on Turkish music today, Tekeliogul writes:

On the one hand, the cultural policies of the young republic that had been imposed by the political powers, and, on the other, a handful of skilled musicians and their listeners from a traditional background that resisted the policies imposed from above. It is within these politico-cultural dynamics that the modern popular music of Turkey has developed. ${ }^{12}$

Today's Turkish music includes every popular style and genre of the world. Stokes does not see this adaption and embrace of popular music as a Western vs. Turkish musical dichotomy but asserts, "(m)ass-mediated popular culture, and popular music in particular, has played an important role in sustaining public life in Turkey" (Stokes 2011, p. 3). He states, "To create a Turkish jazz (or tango, or hip-hop, or electronica) is not simply to import something (and thus recognize a lack), but to exercise and enjoy mastery in rendering it Turkish" (Stokes 2011, p. 20). Similarly, Bates writes:

Ever since the first recordings were made in Turkey in the early 1900s (and perhaps much earlier), musical styles influenced by foreign popular musics of the time have thrived in urban Turkey. However, musicians in Turkey have rarely simply imitated foreign musical styles, but instead create fusions of Anatolian traditions and/or art musics with foreign musical elements. (Bates 2011, p. 73)

Musical styles originating in the West, such as pop, jazz, hip hop, and rock, are popular in Turkey and cannot be fully considered "foreign" or "Western" anymore. As music is localized, these styles of music become central in defining and expressing Turkish identity.

For over a hundred years, Western music styles have been a part of the musical context of Turkey and have been adapted, rearranged, and fused with traditional Turkish music. Although similarities exist between the Western and Turkish counterparts, the Turkish styles are also unique in their language, metaphors, instrumentation, melody, harmony, and rhythm. For example, Turkish pop is often quite distinct from American pop in instrumentation and rhythm. Frequently, traditional Turkish melodic motifs are included in Turkish pop that would not suit American pop..$^{13}$ A Turkish fusion of musical genres does not neglect traditional Turkish music but adapts it to Western conventions or adapts Western styles to Turkish styles.

Traditional Turkish music, both sanat müziği (Turkish urban art music) and halk müziği (Turkish folk music), continues to be popular. However even these traditional styles have been influenced by Western and Eastern music. Historically, these influences have not primarily been a result of colonization or foreign importation but through the localization of Western musical conventions introduced by Turkish leaders and musicians. The debate in 2011 between missionaries and Turkish church leaders about Western translations vs. indigenous hymnody reduces multifaceted issues into a binarism and rarely takes into account the musical reforms of Ataturk or the cultural significance of localization. Within this complex cultural reformation, the Turkish Protestant Church has begun to emerge with its own translated and original hymnody. 


\section{Translations and Identity in Turkish Protestant Worship Music}

Turkey is a modern secular state with a Muslim majority, and less than $0.1 \%$ of the population is Christian (Alliance of Protestant Churches Turkey 2010). Although Protestant missionaries were active within the Ottoman empire, they focused on working with and sometimes converting Armenians and Greeks to become Protestant (Akgün 1989). The modern Turkish Protestant Church is young and relatively small. James Bultema estimates that there are 4000 Turkish Protestant believers in 115 churches with two-thirds of these Christians being Muslim-background believers and one-third coming from historic Christian traditions (Bultema 2013, pp. 4752-54). Although growing, a movement of fewer than 1500 believers from a Muslim background can easily go unnoticed in a nation of nearly eighty-million people. Within the Islamic socio-religious milieu and growing Turkish nationalism, where the mantra "to be a Turk is to be a Muslim", questions of cultural belonging exist as these new Christians attempt to live out their faith (Stiller 2018, p. 188; See also Çağaptay 2006).

Bultema traces the translation of the Bible as key to understanding the rapid growth in the Turkish Protestant Church where the New Testament was translated into modern Turkish in 1988 and the entire Bible in 2000 (Bultema 2013, p. 4779). Although this movement's growth rate has, at times, even surpassed the population growth rate of the country, Turkish Protestant Christianity has not yet been embraced by many within Turkish society, which is primarily identified as secular, nationalistic, and Islamic. According to, Soner Çağaptay, "... Christianity is viewed as alien by the larger Turkish society” and is "a painful situation for the country's small Christian communities" (Çağaptay 2006, p. 1). Within public media, there is often little recognition that there are Christians or pastors, from a Turkish background; instead, Christianity is seen as a foreign import. In Esra Özyürek's view, "there is a national campaign against Christian missionaries and Turkish Christians in Turkey" where a fear of converts to Christianity is fueled by radical nationalist (Özyürek 2009, p. 102). She states, "Nationalist political leaders and activists have accused the Christian/Western powers of trying to conquer Turkey from within by converting its people away from their religion and culture, and from without by annexing Turkey and making it part of the (European) Union" (Özyürek 2009, p. 112). Even with a national "anti-missionary campaign" attempting to prevent foreign missionary activity and conversion, Turkish Christians seem to find meaning and identity in the translation and localization of worship songs from foreign writers.

The first officially published Turkish hymnal, Tanrı'yı Yüceltelim ("Let us Glorify God"), was produced in 1986 and contained a mix of original Turkish hymns, worship songs imported from other Middle Eastern and Eurasian nations, translated traditional hymns, and translated praise songs from the recent Charismatic renewal sweeping American and Europe. ${ }^{14}$ Although multiple updated versions of the hymnal have been published over the past two decades, the hymnal can no longer keep up with the growing number of Western translated songs, and there are no future plans to update the hymnal. In 2010, an electronic Turkish hymnal called Worship Leader (Turkish) was introduced as a free app for computers, tablets, and smartphones.

Several Turkish worship CDs have been produced over the past two decades. Some of these CDs are even in traditional Turkish music styles of sanat müziği and halk müziği, yet the worship songs on these projects are rarely utilized in worship services outside of the churches that produced them. Two of the most popular projects, Seninle Babam and Sözlerin Bittiği Yer, feature Western rock music styles with some traditional Turkish instrumentation. The original Turkish hymns from these two CDs are sung in some of the worship services across the country, but more often, as we will show below, translated contemporary worship songs from England and America are sung.

More than one hundred weekly Evangelical worship gatherings occur in Turkey. Although numerous original Turkish worship songs are published on CDs and in the hymnal, the congregational songs used in these Turkish churches are most often Western translated worship songs with guitar and keyboard-driven music. In recent years, the 
prevalence and availability of global Christian worship music on YouTube and iTunes have increased the use of Western translated songs in Turkey. New worship songs released by Australia's Hillsong United, the UK's Tim Hughes, America's Bethel Music, and other popular worship bands are available in Turkey the moment they are uploaded to the Internet. Songs are then immediately translated and available for use in Turkish worship services. No longer having to wait for a missionary's furlough or a "bootlegged" copy of a new worship CD, Turkish worship leaders have instant access to the most popular worship songs.

In 2011 a survey of eighteen churches was conducted by a major bookstore to determine the most-sung worship songs. ${ }^{15}$ Of these eighteen churches, the top five songs sung originated in USA or the UK and were written in the 1980s or later. Many of the top songs include translations of Integrity Music classics such as "Hosanna", 16 "My Life is In You Lord", ${ }^{17}$ and "As the Deer". ${ }^{18}$ Of the top seventeen songs utilized, there was only one original Turkish hymn and one traditional Middle Eastern setting of the Lord's Prayer. All the rest were Western worship songs. Three of the top seventeen songs sung came from Sonsuzluklar Boyunca, a joint Turkish and Vineyard CD project featuring Turkish worship leaders singing translations of popular Vineyard songs that emerged from the West. ${ }^{19}$ The few churches surveyed that did utilize original Turkish hymnody most often sang songs that they had written themselves. Although original Turkish songs exist, these local churches most often chose to sing translated Western worship songs.

Data from the Worship Leader (Turkish) electronic hymnal have been collected since late 2012. Although the app cannot measure if a song has been sung in a local Turkish church, data is available for the number of individual devices viewing each song. In 2014, the app had around six hundred users who used the app more than three times per month. ${ }^{20}$ Of the top twenty worship songs viewed in $2014,{ }^{21}$ ten were originally Western worship songs translated from English to Turkish, while nine were originally written in Turkish though sometimes by non-Turks. The final song was the same version of the Lord's Prayer as mentioned above. This data reveals that the users of this app are viewing both Western and original Turkish worship songs.

Based on the data from the Worship Leader (Turkish) app, there is a growing interest in original Turkish hymnody. Still, the data from the 2011 survey of songs sung reveal that many congregations chose to sing Western songs translated into Turkish. In his doctoral research, Douglas Clark found, "Many believers ... seem comfortable singing mostly Western worship songs translated into Turkish" (Clark 2012, p. 107) Those who desire to incorporate local musical styles find it difficult to recruit musicians able to play traditional instruments inside and outside of the Christian community (Clark 2012, p. 148) Both Western and local worship hymnodies seem to have an important role in the worshiping life of Turkish churches. For many Turks, Turkish fusion of global genres is the "music of their heart" finding liturgical identity in the localization of "foreign" hymns. ${ }^{22}$ Nonetheless, at the same time, other Turks sense God by the Spirit is "giving a new song to Turkey" that is truly "Turkish". 23

The tension heightens as many Turkish believers connect the meaning of the styles of music with their performance contexts. For example, some believers object to using the Turkish folk music style because it is associated with the drinking culture experienced in the Turkish bars in which it is performed. ${ }^{24}$ Some believers object to Turkish classical music because it is closely related to Islamic Sufi music. Many of these believers see Western translations as neutral and the only appropriate musical style for worship. Some have even indicated that the music of UK Songwriter, Graham Kendrick, is "more anointed" than other worship music. ${ }^{25}$ Concurrently, a few Turkish pastors such as İhsan Özbek and Turgay Üçal are writing songs and releasing new worship albums in these traditional styles.

The complex historical and cultural issues in Turkish music cannot be easily reduced to a divisive binarism of Western translation vs. indigenous. Nevertheless, at the same 
time, genuine questions that are important to Turkish churches' identity and worshiping life exist.

\section{Beyond the Translation vs. Indigenous Hymnody Debate}

The violent metaphor stated by a Turkish believer, who felt that a missionary was shoving a Turkish instrument down his throat, reveals the seriousness of issues in identity and musical worship in the Turkish context. The feelings of another Turk who felt that he had never been able to express his Turkishness in worship highlights a need for more discernment and imagination in local Turkish musical forms.

Attempting to determine a single genuinely indigenous Turkish worship music does not reflect the multi-layered identity of this minority group nor does it recognize the surrounding historical and musical complexities. Clark writes:

Particularly for Turkish MBBs (Muslim Background Believers), 'What shall we sing?' has become an awkward question to answer. Traditional sanat (art) music is urban and elitist. Traditional halk music can be, variously, nationalistic, Alevi, rural, shamanistic, or all four at the same time. The global musics of the Christian world can be too Western in their worldview and expression of Christian faith to be relevant for the Turkish MBB Church. (Clark 2012, p. 106)

The musical worship of this socially persecuted minority reflects a global Christian identity via adapted and translated songs, while also expressing local traditions and musical styles through original songs.

As an important expression of worship, congregational hymnody is an occasion for local communities to identify with and express culture and context. Best states, "Song, almost without exception, is the main musical identifier in any culture" (Best 2003, p. 144). Culture, context, and song are interrelated. Musical styles are often linked with specific cultures and contexts. Moreover, a musical identity of a local church may reflect a global identity finding enormous value and meaning from translocal songs that are localized. ${ }^{26}$ Viewing Turkish musical worship through the lens of musical localization, rather than the translated vs. indigenous binarism, clarifies Turkish Christianity identity within the larger historical, cultural, and musical contexts. For Christians living in a Muslim-majority context, Turks may find religious identification through musical styles and lyrics originating from outside their local context. In the hymnody utilized in Turkish churches in 2011 and viewed on the Worship Leader (Turkish) app in 2014, translated Western worship songs are a fundamental part of a public, corporate expression of Turkish Christian identity in many churches. Musical localization is an essential process that, in the Turkish context, enables a richer understanding of the role. What seems to be foreign musical imports are essential local expressions of corporate religious devotion. Researchers and practitioners should expect that many congregations in Turkey would have a fusion of musical styles and a multiplicity of musical identities consistent with the larger historic musical and cultural trends.

\section{Conclusions}

Suggesting that translated contemporary worship songs are not a part of the religious identity of modern Turkish believers ignores the recent musical history of Turkey and the importance of musical localization within a Christian community. This inquiry and song analysis provide a broader scope of the worship identity of Turkish Protestant Christians. Seeing Turkish hymnody through the lens of localization, enables a fuller view of hymns from the other parts of the globe as carriers of meaning and identity within a local community. The use of both global and local worship songs has notable value in Turkish Christian's liturgical identity and musical expression. Adapted and translated worship songs have been a key expression of worship for Turkish believers for decades. Even with a release of new songs written by Turkish believers, one expression of Turkish Christian identity is a common repertoire of translated worship songs shared by believers around the globe. 
Within the study of the localization of contemporary Christian worship song, the Protestant church in Turkey provides a unique perspective. Where skepticism of foreign influences is embedded within popular media and public policy, the localization of Western contemporary worship song continues. As a developing movement in a minority context, Turkish Protestant Christians express their Turkishness and their Protestant Christian identity through worship song. In their public Christian worship through the use of localized contemporary songs and original hymns, Turks reflect both a global and local liturgical identity.

Funding: This research received no external funding.

Institutional Review Board Statement: Not applicable.

Informed Consent Statement: Informed consent was obtained from all subjects involved in the study.

Conflicts of Interest: The authors declare no conflict of interest.

Appendix A. Top Worship Songs from 2011 Bookstore Survey

\begin{tabular}{|c|c|c|c|}
\hline Turkish Title & $\begin{array}{l}\text { English Title } \\
\text { (If Applicable) }\end{array}$ & Original Turkish & $\begin{array}{l}\text { Original Western or } \\
\text { Non-Turkish }\end{array}$ \\
\hline $\begin{array}{c}\text { Hozana, Hozana, } \\
\text { Hozana } \\
\text { Göklerdekine }\end{array}$ & Hosanna & & $\begin{array}{c}\text { Written by Carl Tuttle; } \\
\text { published by } \\
\text { Integrity Music }\end{array}$ \\
\hline Hayatım Sende Rab & $\begin{array}{l}\text { My Life Is in You } \\
\text { Lord }\end{array}$ & & $\begin{array}{l}\text { Written by Daniel } \\
\text { Gardner; published } \\
\text { by Integrity Music }\end{array}$ \\
\hline $\begin{array}{l}\text { Rab İsmini } \\
\text { Yüceltirim }\end{array}$ & $\begin{array}{l}\text { Lord, I Lift Your } \\
\text { Name on High }\end{array}$ & & $\begin{array}{c}\text { Written by Rick } \\
\text { Founds; published by } \\
\text { Integrity Music }\end{array}$ \\
\hline Baba Senin Sevgin & Father God, I Wonder & & $\begin{array}{c}\text { Written by Ian Smale } \\
\text { published; by } \\
\text { Kingsway's } \\
\text { Thankyou Music }\end{array}$ \\
\hline Övgü ve Yücelik & $\begin{array}{c}\text { There is No One Else } \\
\text { Like You (You } \\
\text { Deserve the Glory) }\end{array}$ & & $\begin{array}{c}\text { Written by Eva Lena } \\
\text { Hellmark }\end{array}$ \\
\hline Bir Kurtarıcı Var & There Is a Redeemer & & $\begin{array}{l}\text { Written by Melody } \\
\text { Green }\end{array}$ \\
\hline $\begin{array}{l}\text { Geyik Suları Nasıl } \\
\text { Özlerse }\end{array}$ & As the Deer & & $\begin{array}{l}\text { Written by Marty } \\
\text { Nystrom; published } \\
\text { by Integrity Music }\end{array}$ \\
\hline Hamt Baba'ya & $\begin{array}{l}\text { Praise God from } \\
\text { Whom All Blessings } \\
\text { Flow (Doxology) }\end{array}$ & & Traditional \\
\hline İsa Egemensin & $\begin{array}{c}\text { Jesus, We Enthrone } \\
\text { You }\end{array}$ & & $\begin{array}{c}\text { Written by Don Moen; } \\
\text { published by } \\
\text { Integrity Music }\end{array}$ \\
\hline $\begin{array}{l}\text { Yüce Rabbim Seni } \\
\text { Seviyorum }\end{array}$ & & $\begin{array}{c}\text { Written by Agnes } \\
\text { Günay and Debora } \\
\text { Basmac1 }\end{array}$ & \\
\hline
\end{tabular}




\begin{tabular}{|c|c|c|c|}
\hline Turkish Title & $\begin{array}{l}\text { English Title } \\
\text { (If Applicable) }\end{array}$ & Original Turkish & $\begin{array}{l}\text { Original Western or } \\
\text { Non-Turkish }\end{array}$ \\
\hline Korkma Seninleyim & Fear not! & & $\begin{array}{l}\text { Written by Phil } \\
\text { Pringle }\end{array}$ \\
\hline $\begin{array}{l}\text { Rabbin Sarsılmaz } \\
\text { Sevgisi Hiç } \\
\text { eksilmez. }\end{array}$ & $\begin{array}{c}\text { The Steadfast Love of } \\
\text { the Lord }\end{array}$ & & $\begin{array}{l}\text { Written by Robert } \\
\text { Davidson }\end{array}$ \\
\hline $\begin{array}{l}\text { Ey Göklerdeki } \\
\text { Babamız }\end{array}$ & & & $\begin{array}{c}\text { Traditional Middle } \\
\text { Eastern possibly Arab } \\
\text { or Persian origin }\end{array}$ \\
\hline $\begin{array}{c}\text { Gel Rab'be } \\
\text { Tapınalım Gel }\end{array}$ & $\begin{array}{l}\text { Come, Now is the } \\
\text { Time for Worship }\end{array}$ & & $\begin{array}{c}\text { Written by Brian } \\
\text { Doerksen; published } \\
\text { by Mercy/Vineyard }\end{array}$ \\
\hline $\begin{array}{l}\text { Ben Zayıfken Sen } \\
\text { Gücümsün }\end{array}$ & All in All & & $\begin{array}{c}\text { Written by Dennis } \\
\text { Jernigan; published } \\
\text { by Maranatha }\end{array}$ \\
\hline Beni Yaklaştır & Draw Me Close & & $\begin{array}{c}\text { Written by Marie } \\
\text { Barnett; published by } \\
\text { Mercy/Vineyard }\end{array}$ \\
\hline Tüm Susayanlar & All Who Are Thirsty & & $\begin{array}{l}\text { Written by Brenton } \\
\text { Brown and Glenn } \\
\text { Robertson; published } \\
\text { by Mercy/Vineyard }\end{array}$ \\
\hline
\end{tabular}

Appendix B. Top Songs Viewed on Worship Leader (Turkish) in 2014

\begin{tabular}{|c|c|c|c|}
\hline Turkish Title & $\begin{array}{l}\text { English Title } \\
\text { (If Applicable) }\end{array}$ & Original Turkish & $\begin{array}{l}\text { Original Western or } \\
\text { Non-Turkish }\end{array}$ \\
\hline Lütfun Yeter & Your Grace Is Enough & & $\begin{array}{c}\text { Written by Matt } \\
\text { Maher; published by } \\
\text { Thankyou Music }\end{array}$ \\
\hline Baba, Senin Sevgin & Father God I Wonder & & $\begin{array}{c}\text { Written by Ian Smale; } \\
\text { published by } \\
\text { Kingsway's } \\
\text { Thankyou Music }\end{array}$ \\
\hline Övgü Ve Yücelik & $\begin{array}{c}\text { There is No One Else } \\
\text { Like You (You } \\
\text { Deserve the Glory }\end{array}$ & & $\begin{array}{c}\text { Written by Eva Lena } \\
\text { Hellmark }\end{array}$ \\
\hline Beni Sevdin Rab & & Written by Ali Övek & \\
\hline $\begin{array}{c}\text { İsa Mesih, Tanrı'nın } \\
\text { Oğlu }\end{array}$ & & $\begin{array}{l}\text { Written by Gürkan } \\
\text { Çamsun }\end{array}$ & \\
\hline Avlularına Al Beni & Take Me In & & $\begin{array}{l}\text { Written By David } \\
\text { Browning }\end{array}$ \\
\hline Öveceğim Sonsuzca & & $\begin{array}{l}\text { Written by Tülin } \\
\text { Ekinci }\end{array}$ & \\
\hline $\begin{array}{l}\text { Ben Zayıfken Sen } \\
\text { Gücümsün }\end{array}$ & All in All & & $\begin{array}{l}\text { Written by Dennis } \\
\text { Jernigan; published } \\
\text { by Maranatha }\end{array}$ \\
\hline
\end{tabular}




\begin{tabular}{|c|c|c|c|}
\hline Turkish Title & $\begin{array}{l}\text { English Title } \\
\text { (If Applicable) }\end{array}$ & Original Turkish & $\begin{array}{l}\text { Original Western or } \\
\text { Non-Turkish }\end{array}$ \\
\hline $\begin{array}{l}\text { Ey Göklerdeki } \\
\text { Babamız }\end{array}$ & & & $\begin{array}{l}\text { Traditional Middle } \\
\text { Eastern possibly Arab } \\
\text { or Persian origin }\end{array}$ \\
\hline Gör O'nun & See His Love & & $\begin{array}{l}\text { Written by Tom } \\
\text { Lockley; published by } \\
\text { Thankyou Music }\end{array}$ \\
\hline Muhteşem & & $\begin{array}{l}\text { Written by unnamed } \\
\text { published by Yaşam } \\
\text { Kilesesi }\end{array}$ & \\
\hline İsa Hükmediyorsun & & $\begin{array}{c}\text { Written by unnamed } \\
\text { published by Yaşam } \\
\text { Kilesesi }\end{array}$ & \\
\hline O'nu İzleyeyim & & $\begin{array}{l}\text { Written by Amy } \\
\text { Ohler }\end{array}$ & \\
\hline Işık Kaynağı & $\begin{array}{l}\text { Here I Am to Worship } \\
\text { (Light of the Word) }\end{array}$ & & $\begin{array}{l}\text { Written by Tim } \\
\text { Hughes; published by } \\
\text { Thankyou Music }\end{array}$ \\
\hline Haydi Haydi & Yallah Yallah & & $\begin{array}{l}\text { Written by Evan } \\
\text { Rogers }\end{array}$ \\
\hline Görkemli İsa & You Are Full of Grace & & $\begin{array}{l}\text { Written by Evan } \\
\text { Rogers }\end{array}$ \\
\hline Rab Çobanımdır & & $\begin{array}{c}\text { Written by Can } \\
\text { Tanyar }\end{array}$ & \\
\hline Dünya Dolsun & & $\begin{array}{l}\text { Written by Adrienne } \\
\text { Neusch }\end{array}$ & \\
\hline Tanrımız Ne Yüce & $\begin{array}{l}\text { How Great is Our } \\
\text { God }\end{array}$ & & $\begin{array}{c}\text { Written by Chris } \\
\text { Tomlin and cowriters; } \\
\text { published by } \\
\text { worshiptogether.com } \\
\text { and others }\end{array}$ \\
\hline $\begin{array}{l}\text { Yaklaşalım } \\
\text { Babamıza }\end{array}$ & & $\begin{array}{c}\text { Written by unnamed } \\
\text { published by Yaşam } \\
\text { Kilesesi }\end{array}$ & \\
\hline
\end{tabular}

\section{Notes}

1 In the context of this debate, Western music typically refers to contemporary worship songs that have been utilized in local churches in the West (e.g., USA, UK, Australia) and widely distributed via a global commercial music industry. In the Turkish context, indigenous music most often defined as native Turkish musical forms and instrumentation. Though other cultural contexts make a strong distinction between hymn and worship song, discussions in the Turkish context often utilize the terms interchangeably. In Turkish, ilahi is utilized which refers to a religious hymn. In this paper, the terms will be according to the Turkish convention. See (Redman 2002; Ingalls 2008; Chupungco 2002, pp. 244-51).

Interview with early Christian minister in Turkey, 6 March 2012. Specific names and locations are withheld due to security concerns. The saz is a long-necked lute associate with traditional Turkish musics.

3 Interview with Turkish worship leader, 1 June 2012.

$4 \quad$ Terms such as worship, liturgy, and liturgical are intentionally utilized interchangeably to enable this article to be situated within the current scholarship surrounding Free Church liturgical theology and contemporary worship's contributions to liturgical identities. See (Ross 2014; Ellis 2004; Cherry 2010).

$5 \quad$ Ingalls, Monique, Carolyn Landau, and Tom Wagner. 2013. Prelude. In (Ingalls et al. 2013, pp. 5-6).

6 As cited in Tekeliogul, Orhan. 2004. An Inner History of 'Turkish Music Revolution'. In (Özdalga 2004, p. 112).

7 As cited in Tekeliogul, An Inner History of 'Turkish Music Revolution'. p. 101. 
Tekeliogul, An Inner History of 'Turkish Music Revolution', pp. 111-12.

Tekeliogul, An Inner History of 'Turkish Music Revolution', p. 105.

Translated by the author as "Be happy! That's an order!".

Translated by the author.

Tekeliogul, An Inner History of 'Turkish Music Revolution', p. 113.

For example, Turkish pop sensation, Tarkan's Dudu received an international reception but the melodic, rhythmic and instrumentation would seem out of place in most American pop music. See Tarkan. 2012. Dudu. Available online: https:/ / www.youtube.com/watch?v=SCZgGVqVsbY (accessed on 15 July 2021).

14 Interview with early Christian minister in Turkey who was active in compiling the hymnal, 6 March 2012. Interview with bookstore owner, 25 February 2012. See Appendix A: Top Worship Songs from 2011 Bookstore Survey.

Words and music by Carl Tuttle. An audio sample available at https://youtu.be/mT1r2PJoaO8 (accessed on 16 October 2021). Words and music by Daniel Gardner. An audio sample available at https:/ /youtu.be/pyNiYHfj3qs (accessed on 16 October 2021).

Words and music by Martin Nystrom. An audio sample available at https://youtu.be/t9LoiE1gzeU (accessed on 16 October 2021).

Vineyard Resources. n.d. Sunsuzluklar Boyunca. Available online: http://www.vineyardresources.com/equip/content/turkishsonsuzluklar-boyunca-cd (accessed on 9 January 2015).

Worship Leader (Turkish) developer, e-mail message to author, 22 December 2014. The app often seems to be utilized to access new songs that are not available in previous versions of the Turkish hymnal. Turkish congregations could be singing these older songs but not downloading or viewing them on the app because they can obtain them from other sources.

See Appendix B: Top Songs Viewed on Worship Leader (Turkish) in 2014.

Interview with Turkish worship leader, 26 January 2012.

Interview with early Christian minister in Turkey, 6 March 2012.

Interview with Turkish ethnomusicologist, 6 March 2012. See also Clark, Turkish Halk Music, p. 142.

Interview with Turkish ethnomusicologist, 6 March 2012. Kendrick's music has been very influential in Turkey. His influence began in the 1980s with a "March for Jesus" rally during a season of exponential growth in the Turkish church. Kendrick's book on worship is the only book on worship currently available in Turkish Christian bookstores. See (Kendrick 1996).

Translocal songs are songs written by Christians from other cultures that are shared across cultures. See (Kim 2013).

\section{References}

Akgün, Seçil. 1989. The Turkish Image in the Reports of American Missionaries in the Ottoman Empire. Turkish Studies Association Bulletin 13: 91-105.

Alliance of Protestant Churches Turkey. 2010. Letter from Turkish Church. Available online: http:/ /www.prayforturkey.com/letterenglish-full.html (accessed on 14 April 2010).

Bates, Eliot. 2011. Music in Turkey: Experiencing Music, Expressing Culture. New York: Oxford University Press.

Best, Harold. 2003. Unceasing Worship: Biblical Perspectives on Worship and the Arts. Downers Grove: InterVarsity.

Bultema, James. 2013. Against Wind and Waves: The Countercultural Movement of a Turk and the Turkish Protestant Church. In Longing for Community: Church, Umma, or Somewhere in Between. Edited by David Greenlee. Pasedena: William Carey Library.

Çağaptay, Soner. 2006. Islam, Secularism, and Nationalism in Modern Turkey. New York: Routledge.

Cherry, Constance M. 2010. The Worship Architect: A Blueprint for Designing Culturally Relevant and Biblically Faithful Services. Grand Rapids: Baker Academic.

Chupungco, Anscar J. 2002. Inculturation. In The New Westminister Dictionary of Liturgy and Worship. Edited by Paul Bradshaw. Louisville: Westminister John Know Press, pp. 244-51.

Clark, Douglas F. 2012. Turkish Halk Worship Music: The Muslim Background Believer Churches of Turkey at Worship in the Language of Their Own People. Ph.D. thesis, Assemblies of God Theological Seminary, Springfield, MO, USA.

Ellis, Christopher J. 2004. Gathering: A Theology and Spirituality of Worship in Free Church Tradition. London: SCM Press.

Erguner, Kudsi. 2005. Journeys of a Sufi Musician. Translated by Annette Courtenay Mayers. London: Saqi.

Ingalls, Monique M. 2008. Awesome in This Place: Sound Space, and Identity in Contemporary North American Evangelical Worship. Ph.D. thesis, University of Pennsylvania, Philadelphia, PA, USA.

Ingalls, Monique M., Carolyn Landau, and Tom Wagner, eds. 2013. Christian Congregational Music: Performance, Identity, and Experience. Surrey: Ashgate.

Ingalls, Monique M., Muriel Swijghuisen Reigersber, and Zoe C. Sherinian, eds. 2018. Making Congregational Music Local in Christian Communities Worldwide. London: Routledge.

Kendrick, Graham. 1996. Tapınma. Translated by Levent Kınran. Istanbul: Yeni Yaşam Yayınları.

Kim, Jaewoo. 2013. The Whole World Has Gone 'Glocal'. In Worship and Mission or the Glocal Church: An Ethnodoxology Handbook. Edited by James R. Krabill. Pasadena: William Carey Library. 
Lim, Swee Hong. 2017. Forming Christians through Musicking in China. Religions 8: 50. Available online: http://www.mdpi.com/20 77-1444/8/4/50/pdf (accessed on 7 October 2021). [CrossRef]

Magowan, Fiona. 2007. Globalisation and Indigenous Christianity: Translocal Sentiments in Australian Aboriginal Christian Songs. Identities: Global Studies in Culture and Power 14: 469-70. [CrossRef]

Öncel, Misra. n.d. Ottoman Sounds. Translated by Attilla Eröncel. Istanbul: Boyut Publishing Group.

Özdalga, Elisabeth. 2004. Sufism, Music and Society in Turkey and the Middle East. Swedish Research Institute in Istanbul Transactions. Istanbul: Taylor \& Francis e-Library, vol. 10.

Özyürek, Esra. 2009. Convert Alert: German Muslims and Turkish Christians as Threats to Security in the New Europe. Comparative Studies in Society and History 51: 91-116. [CrossRef]

Redman, Robb. 2002. The Great Worship Awakening: Sing a New Song in the Postmodern Church. San Francisco: Jossey-Bass.

Ross, Melanie C. 2014. Evangelical Versus Liturgical?: Defying a Dichotomy. Grand Rapids: Eerdmans.

Steuernagel, Marcell Silva. 2021. Church Music Through the Lens of Performance. London: Routledge.

Stiller, Brian C. 2018. From Jerusalem to Timbuktu: A World Tour of the Spread of Christianity. Downers Grove: IVP.

Stokes, Martin. 2011. The Republic of Love: Cultural Intimacy in Turkish Popular Music. Chicago: University of Chicago Press.

Thornton, Daniel. 2021. Meaning-Making in the Contemporary Congregational Song Genre. London: Palgrave Macmillan.

Whittaker, Sue. 2019. A Turkish Musical Insider Case Study: Liturgy, Self-Identity and Spiritual Formation. Available online: https://www.academia.edu/40219633/_Dissertation_A_TURKISH_MUSICAL_INSIDER_CASE_STUDY_LITURGY_SELF_ IDENTITY_AND_SPIRITUAL_FORMATION?auto=download (accessed on 7 October 2021).

Wood, Robert, and Brian Walrath, eds. 2007. The Message in the Music: Studying Contemporary Praise and Worship. Nashville: Abingdon. 